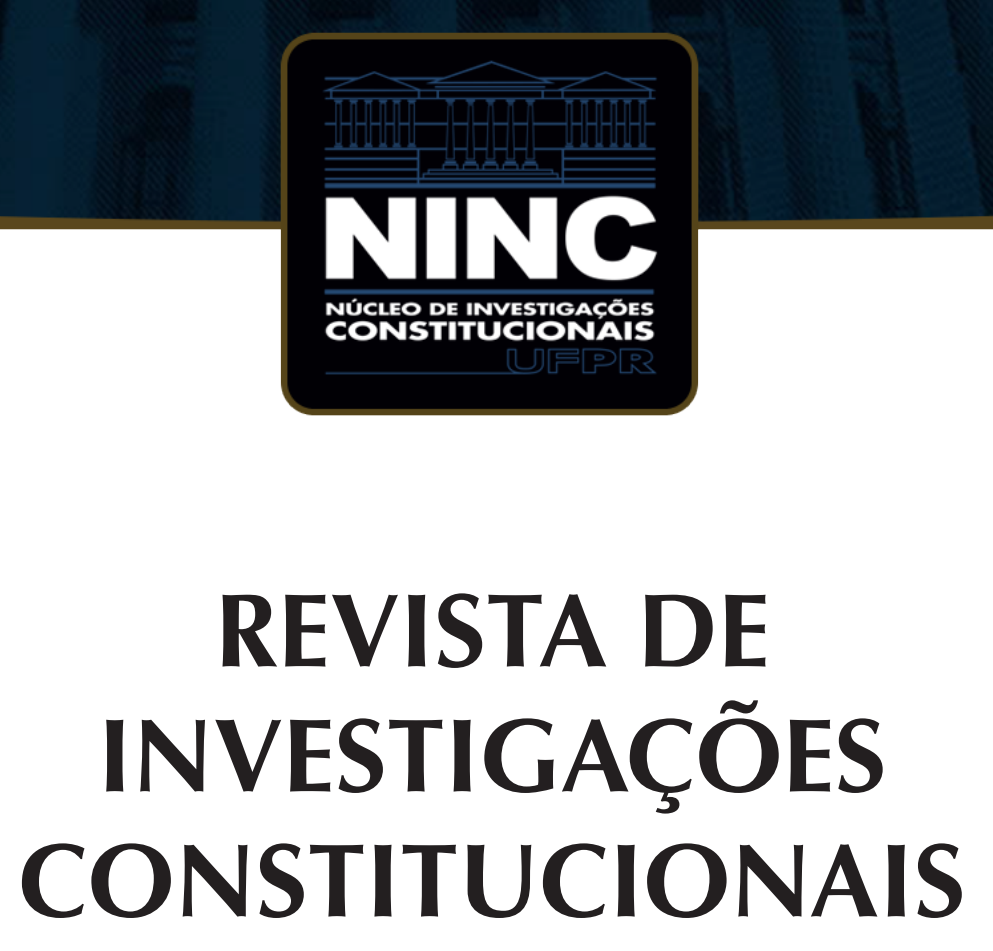

JOURNAL OF CONSTITUTIONAL RESEARCH

vol. 5 | n. 1 | janeiro/abril 2018 | ISSN 2359-5639 | Periodicidade quadrimestral Curitiba | Núcleo de Investigações Constitucionais da UFPR | www.ninc.com.br 


\section{O ativismo judicial e constrangimentos a posteriori}

\section{Judicial activism and a posteriori constraints}

\section{LUIZ HENRIQUE DINIZ ARAÚJO*}

Faculdade Boa Viagem/DeVry (Brasil) http://orcid.org/0000-0001-7682-0038 luizdinizaraujo@hotmail.com

Recebido/Received: 29.10.2017 / October 29th, 2017 Aprovado/Approved: 30.12.2017 / December 30th, 2017

\section{Resumo}

O presente artigo se propõe a analisar o ativismo judicial, expressão de significado impreciso e fugidio no nosso Direito. Após estabelecer algumas premissas para a definição teórica do ativismo judicial, passa a analisar, ainda no campo teórico, que o ativismo demanda limites e que os constrangimentos meramente hermenêuticos (ou constrangimentos a priori) não são suficientemente eficazes. Partindo dessa constatação, passa a analisar limites práticos (limites a posteriori) ao ativismo, como a interpretação evolutiva (incrementalismo) e o respeito aos precedentes. Em sua parte final, o trabalho analisa um julgamento emblemáticos do Supremo Tribunal Federal, correlacionando-o com o significado de ativismo judicial exposto, bem como com a aplicação prática dos constrangimentos a posteriori.

Palavras-chave: ativismo judicial; constrangimentos; precedentes; incrementalismo; Supremo Tribunal Federal.

\section{Abstract}

This paper aims to analyze judicial activism, an expression that still demands a precise meaning in Brazilian legal literature. Firstly, the text exposes a couple of meanings the expression judicial activism may assume in Brazilian Law; it also explores the need of constraints to judicial activism other than mere interpretive ones. Thus, the text analyses a posteriori constraints, such as binding precedents and incrementalism. In its third part, the paper explores a Brazilian Supreme Court in emblematic case, connecting it to the theories and constraints previously exposed.

Keywords: judicial activism; constraints; precedents, incrementalism; Brazilian Supreme Court.

Como citar esse artigo/How to cite this article: ARAÚJO, Luiz Fernando Diniz. O ativismo judicial e constrangimentos a posteriori. Revista de Investigações Constitucionais, Curitiba, vol. 5, n. 1, p. 129-150, jan./abr. 2018. DOI: 10.5380/rinc.v5i1.56088

* Professor da Faculdade Boa Viagem/DeVry (Recife, PE, Brasil). Doutor pela Universidade Federal de Pernambuco (Recife, PE, Brasil). Mestre pela Universidade Federal de Pernambuco (Recife, PE, Brasil). Visiting Researcher na University of California, Berkeley (California, EUA). Estágio Pós-Doutoral na Université Paris 1 Panthéon-Sorbonne. Procurador Federal. Coordenador Nacional de Direito Processual Civil da Escola da Advocacia-Geral da União. Professor de Direito Constitucional e Direito Processual Civil da Escola da AGU. Coordenador da área Fazenda Pública da Escola Superior da Advocacia Ruy Antunes - ESA/PE. Membro do Grupo REC de Estudos Constitucionais. Membro da Associação Norte e Nordeste de Professores de Processo. E-mail: luizdinizaraujo@hotmail.com. 


\section{SUMÁRIO}

1. Introdução; 2. Ativismo Judicial; 2.1. A polissemia da expressão ativismo judicial; 2.2. Ativismo judicial no Brasil; 3. Os constrangimentos a posterori à discricionariedade: vinculação aos precedentes e interpretação evolutiva (incrementalismo); 3.1. Constrangimentos interpretativos; 3.2. O constrangimento representado pelo respeito aos precedentes; 3.3. $O$ incrementalismo ou a interpretação constitucional evolutiva; 4. Análise de casos julgados pelo Supremo Tribunal Federal: incrementalismo (jurisprudência evolutiva) e respeito a precedentes; 4.1. O caso das Uniões Homoafetivas (ADI 4.277 e da ADPF 132); 5. Conclusões; 6 . Referências.

\section{INTRODUÇÃO}

Com o reconhecimento da força normativa da constituição em uma pluralidade de Estados nacionais e da jurisdição constitucional em diversos deles, muito se tem discutido a respeito da interpretação e da efetivação das ideias difusas congregadas nos textos constitucionais.

A esse fenômeno tem correspondido o crescimento do papel do poder judiciário no Brasil e em diversos outros países, como é o caso dos Estados Unidos da América e da República Francesa, do Estado de Israel, da Colômbia, do Chile, do Canadá, do Japão, entre diversos outros. Esse fenômeno de afirmação do Poder Judiciário no exercício de seu papel contramajoritário tem, em alguns momentos, aberto ensanchas ao que se tem denominado de ativismo judicial, conceito dotado de grave polissemia e que será analisado no texto de forma detalhada.

Assumindo que práticas ativistas devem ser evitadas, pelas razões que serão expostas, o texto, além de analisar o ativismo enquanto conceito, estudará, outrossim, em que medida e por que meios é possível, de alguma forma, criar constrangimentos (constraints) às práticas ativistas. No contexto do tema, entendam-se como constrangimentos forças que agem no sentido de manter a decisão judicial dentro de certos parâmetros que, para serem desbordados, precisam ser enfrentados na fundamentação e por ela superados, ou seja, com ônus argumentativo necessário.

Nesse sentido, o constrangimento age para equilibrar o saudável exercício da jurisdição constitucional - essencial, em nosso entender, ao bom funcionamento das democracias liberais, pois que confere efetividade a direitos fundamentais - com a noção de que a criação de direitos pelos juízes deve encontrar limites, sob pena de usurpação da atividade legislativa e deslegitimação do próprio Poder Judiciário, o que não é, na visão esposada pelo trabalho, desejável.

Cabe esclarecer, ainda à guisa de introdução, que serão diferenciados no texto os contrangimentos ditos a priori dos constrangimentos a posteriori. Ambos podem atuar como forças contrárias ao ativismo, no sentido de trazer a interpretação e 
a fundamentação ao campo da racionalidade e da maior objetividade possíveis, sendo essas as características que lhes são comuns.

De outro lado, como notas distintivas, os constrangimentos a priori se situam notadamente no campo da interpretação, ou seja, são os primeiros constrangimentos, a agir independentemente de qualquer consideração a precedentes ou a uma linha jurisprudencial evolutiva. Os constrangimentos a posteriori, por sua vez, podem atuar no sentido da maior objetividade na fundamentação de uma decisão judicial e são representados, conforme analisa o artigo, pelos precedentes e pela interpretação evolutiva da constituição.

O problema a ser analisado, portanto, é a fragilidade dos constrangimentos meramente hermenêuticos postos aos juízes e tribunais por teorias interpretativas. Essa fragilidade e insuficiência por vezes enseja um excessivo subjetivismo das decisões judiciais e, por via de consequência, a um deficit democrático do Poder Judiciário.

Dessa forma, o objetivo do trabalho é propor outros constrangimentos, que não os meramente propostos por teorias da interpretação, que atuem de forma mais eficaz no sentido da maior objetividade das decisões judiciais.

A hipótese de trabalho é de que esses constrangimentos práticos (também chamados a posteriori) conferem uma maior objetividade às decisões, ou seja, mantêm as decisões judiciais mais ou menos adstritas a certos parâmetros traçados previamente pela aplicação do Direito a situações concretas pelo próprio Poder Judiciário.

A metodologia adotada foi a revisão bibliográfica sobre os temas tratados, bem como estudo de um caso julgado julgado pelo Supremo Tribunal Federal que o texto aponta como um modelo a ser seguido em relação à atenção a constrangimentos representados pelos precedentes e pela interpretação evolutiva da Constituição.

\section{ATIVISMO JUDICIAL}

Conforme antecipado na Introdução, o ativismo judicial será estudado neste trabalho como uma prática a ser evitada, no exercício da jurisdição constitucional, sob pena de usurpação da função legislativa pelo poder judiciário, bem como de deslegitimação desse poder. De toda sorte, antes de tudo é necessário enfrentar a polissemia que carrega a expressão ativismo judicial para, somente após, passarmos à demonstração de algumas das formas como pode se revelar na prática da jurisdição constitucional.

\subsection{A polissemia da expressão ativismo judicial}

A expressão ativismo judicial é extremamente polissêmica, podendo designar desde a prática judiciária de iniciativa em termos instrutórios até a frequência com que uma corte ou tribunal constitucional invalida atos normativos dos demais poderes. $\mathrm{A}$ 
esse respetivo, é especialmente didática a lição de Keenan $\mathrm{Kmiec}^{1}$, que menciona cinco acepções da expressão ativismo judicial ("judicial activism"), a denotar a multidimensionalidade do conceito.

Em um primeiro sentido, Kmiec diz que pode ser considerada ativista a atitude do poder judiciário de invalidar as ações dos demais poderes do Estado. Nesse sentido, seria ativista um tribunal ou uma corte que com regularidade agisse no sentido de declarar inconstitucionais atos normativos dos demais poderes estatais.

Em um segundo sentido, a expressão ativismo judicial designaria a atitude de um tribunal de se afastar dos precedentes que deveria respeitar, ou seja, quando adote uma visão própria do que é o Direito em detrimento da visão e da interpretação já consagradas em precedentes.

Em um terceiro sentido, o ativismo judicial se revelaria quando a corte, em detrimento de julgar, passasse a legislar. Nas palavras de Continentino2, "Cortes ativistas seriam aquelas que, ao desprezarem os limites de suas próprias atribuições e o princípio da separação dos poderes, criariam direito novo, a pretexto de interpretá-lo".

Em um quarto sentido, ativista seria o procedimento do tribunal que se afasta de uma metodologia interpretativa aceita.

Por fim, Kmiec traz o critério do julgamento orientado pelo resultado (result-oriented judgement). Dessa forma, a decisão seria ativista quando o juiz tiver um motivo finalístico para decidir em um certo sentido e quando a decisão se afastar do que seria considerado razoável.

Essas significados dão conta do quão polissêmica é a expressão ativismo judicial, carregada que é de ambiguidades e inconsistências. Para os fins deste trabalho, interessam-nos os quatro últimos sentidos utilizados por Kmiec, ou seja: (i) tribunal se afasta de precedentes sem o devido ônus argumentativo; (ii) tribunal, em vez de julgar, passa a a legislar (legislate from the bench); (iii) tribunal se afasta de uma metodologia interpretativa aceita; (iv) julgamento orientado pelo resultado.

É inegável que a expansão do poder jurisdicional levou à tão conhecida atividade criativa do juiz, a significar que compete ao magistrado mais do que a proteção, mas também a criação de direitos. Esse movimento não acontece sem reações, que denunciam a marginalização dos agentes político-representativos, com a flagrante redução da importância do poder legislativo3.

\footnotetext{
1 KMIEC, Keenan. The origin and current meaning of "judicial activism". Disponível em http://www.constitution.org//rev/ $\mathrm{kmiec/judicial \_ activism.htm.} \mathrm{Acesso} \mathrm{em} \mathrm{08.07.2014.}$

2 CONTINENTINO, Marcelo Casseb. Ativismo Judicial. Proposta para uma discussão conceitual. Revista de Informação Legislativa, Brasília, a. 49, n. 193, p. 141-149, jan/mar 2012. p. 143.

3 ROMBOLI, Roberto. A função interpretativa do juiz comum e a influência sobre ela exercida pela jurisprudência constitucional. In: ROMBOLI, Roberto; ARAÚJO, Marcelo Labanca Corrêa de (Coord.). Justiça Constitucional e Tutela Jurisdicional dos Direitos Fundamentais. Belo Horizonte: Arraes Editores, 2015, p. 40-60. p. 51.
} 
Assim, o ativismo é um conceito que traz em si um dualismo: de um lado, é necessário aos estados constitucionais e permitem o aprofundamento dos direitos que se propõem a reconhecer e efetivar, o que implica uma certa margem de discricionariedade judicial; de outro, a sua exacerbação pode levar à deslegitimação do estado de direito 4 . Entenda-se como discricionariedade judicial, no contexto deste artigo, a margem de decisão que decorre da vontade do intérprete 5 , que não é negada por nós mas que, em nossa visão, deve ser restringida na medida do possível, para que a decisão tenha uma fundamentação o mais racional possível.

Desprezaremos o primeiro critério exposto por Kmiec, uma vez que, em nossa avaliação, trata-se de um critério inconsistente, sem significado importante, uma vez que o fato de uma corte ou tribunal constitucional invalidar atos dos demais poderes e com que frequência o faz, por si, não conduz a conclusões importantes. Sim, pois os atos normativos podem haver sido invalidados por conterem efetivamente flagrantes inconstitucionalidades, por exemplo, o que nada quer dizer em relação ao ativismo judicial.

Os quatro critérios restantes, por outro lado, em nossa concepção, podem servir de base a uma análise bastante interessante sob a ótica dos limites da fundamentação das decisões judicias, ou seja, se são mais ou menos discricionárias, ou, sob outro ângulo de visada, mais ou menos constrangidas.

Vistos com cuidado, esses critérios de (i) a (iv) acima têm um ponto fundamental em comum e, talvez, pudessem mesmo ser reduzidos a um único critério, traduzido pela seguinte pergunta: quão livremente pode um juiz ou um tribunal fundamentar suas decisões? Essa é a pergunta cuja resposta nos interessa neste trabalho, a qual, por sua vez, pode ser desdobrada nas seguintes: existem parâmetros além dos meros textos e suas técnicas de interpretação para que uma decisão no âmbito da jurisdição constitucional seja considerada adequada? Ou pode o juiz constitucional decidir da forma que lhe aprouver, desde que lastreie sua fundamentação em textos normativos aplicando uma determinada metodologia? Caso existam esses outros parâmetros, quais são eles?

\section{2. $O$ ativismo judicial no Brasil}

Nos Estados Unidos, a prática judiciária e os críticos já têm longa tradição e experiência no que diz respeito ao tema do ativismo judicial, sendo sua teoria e prática um manancial para quem quer se debruçar sobre o tema. No entanto, é importante, ao traçar paralelos e trazer a experiência e a literatura estadunidenses à realidade

\footnotetext{
4 NOBRE JÚNIOR, Edílson Pereira. Ativismo judicial: possibilidade e limites. Revista de Direito Administrativo e Constitucional, Belo Horizonte, n. 43, ano 11, p. 92-117, jan./mar. 2011. p. 110.

5 STRECK, Lenio Luiz. Verdade e Consenso. São Paulo: Saraiva. 2012. P. 38.
} 
brasileira, ter em conta que o ativismo que se tem verificado no Brasil até o momento difere daquele que se verifica nos EUA, ao menos em um aspecto fundamental: lá, algumas decisões da Suprema Corte que restrigem direitos fundamentais são apontadas como ativistas, ao passo que, no Brasil, praticamente se formou um senso comum de que o Supremo Tribunal Federal apenas é ativista para amplificar direitos fundamentais.

Na realidade norte-americana, um dos casos em que se atribui à Suprema Corte a prática de um ativismo restritivo a direitos fundamentais é o famoso Dred Scott $v$. Sandford, conhecido simplesmente como caso Dred Scott. Em 1820, o Missouri Compromise foi assinado proibindo a escravidão em novos territórios existentes acima de certa latitude da superfície norte-americana.

Com fundamento no Missouri Compromise, o escravo Dred Scott ingressou com ação postulando o seu direito à liberdade por ter estado em por ter estado em território em que era vedada a escravidão, por força do Missouri Compromise.

Provocada, a Suprema Corte dos Estados Unidos denegou a pretensão, sob o fundamento de que os negros, mesmo livres ou libertos, não podiam se tornar cidadãos, condição que os impediria de ser parte em processos judiciais. Na mesma decisão, a Suprema Corte fundamentou na cláusula do devido processo legal substantivo que o Missouri Compromise era inconstitucional, pois privava um cidadão dos Estados Unidos de sua propriedade sem justificativa plausível, no caso, o proprietário do escravo Dred Scott.

Além desse, há outros exemplos clássicos de ativismo em que a Suprema Corte dos Estados Unidos restringiu direitos fundamentais, como julgamentos da chamada Era Lochner, no início dos anos 1900, no contexto da quebra da bolsa de Nova lorque e da adoção das políticas econômicas de matriz keynesiana sob regência do Presidente Franklin Delano Roosevelt (New Deal).

As políticas adotadas no contexto do New Deal contemplavam o reconhecimento a alguns direitos trabalhistas, como piso salarial e limitação de jornada de trabalho, mas sofreram contestações que desaguaram na Suprema Corte que, em muitos dos julgamentos, como foi o caso de Adkins v. Children`s Hospital (1923) invalidou ato normativo que fixava pisos salariais para mulheres e crianças, sob o argumento de que o due process of law impedia o legislador de interferir na liberdade contratual e na livre iniciativa.

Esses são apenas alguns exemplos que demonstram que as chamadas decisões ativistas, nos Estados Unidos, por vezes caminharam no sentido da restrição a alguns direitos fundamentais ou para conter os demais poderes, enquanto no Brasil há autores que registram que, até o presente e no âmbito do Supremo Tribunal Federal, as decisões apontadas como ativistas têm caminhado na direção de expandir direitos 
fundamentais sob o fundamento de suprir as deficiências pela inação dos demais poderes. Daí a preocupação com a assim chamada "legislação judiciária" e o "ativismo à brasileira".

Uma das causas para essa característica do ativismo no Brasil pode estar na cláusula constitucional do amplo acesso à justiça, que, nas palavras de Hermes Zaneti Jr.7, torna o Poder Judiciário um "motor da democracia participativa". Tudo isso foi potencializado com a transformação do discurso jurídico e judicial pós-1988, passando-se de um "discurso fundado em regras codificadas, centralizado no juiz, apodítico e demonstrativo, que aplicava o direito material posto e fundado nos direitos subjetivos preconcebidos, para um discurso democrático", com viés argumentativo, como decorrência da "principialização do direito".

Efetivamente, a partir da Constituição de 1988, o papel do poder judiciário no país passou e vem passando por profunda transformação. Diversas mudanças no ambiente institucional levaram à ampliação do acesso à justiça, ao fortalecimento do Ministério Público, bem como ao reforço de instrumentos processuais, como as ações civis públicas. Ademais, as liberdades democráticas têm conduzido a uma maior consciência dos cidadãos em relação a seus direitos ${ }^{8}$.

Todos esses fatores convergiram para o fenômeno da maior litigiosidade, da judicialização da política, como já abordado acima, e do processo de "empoderamento" (empowerment) do judiciário, que exercem pressão exacerbada sobre esse poder, abrindo margem a uma postura mais ativista, no sentido de ter que dar respostas a graves problemas sociais, econômicos e institucionais, apenas para não alongarmos a lista.

O processo de"empoderamento" pós-Constituição de 1988 tem alguns marcos importantes, pontuados abaixo:

(i) a Constituição de 1988 criou um modelo político que não é puramente majoritário, assegurando inúmeros direitos fundamentais;

(ii) o Supremo Tribunal Federal foi dotado de diversas competências originárias: ação direta de inconstitucionalidade de lei ou ato normativo federal ou estadual (art. $102, \mathrm{I}, a$ ); ação direta de inconstitucionalidade por omissão (art. 102, § 2. ${ }^{\circ}$ ); arguição de descumprimento de preceito fundamental (art. 102, p.u.); mandado de injunção para sanar omissão de norma regulamentadora que torne inviável o exercício de direitos e liberdades constitucionais, assim como prerrogativas inerentes à nacionalidade, à soberania e à cidadania (art. 5, LXXI); mandado de segurança e habeas data contra atos de autoridades sujeitas à sua jurisdição (art. 102, l, d). O controle difuso foi mantido

6 RAMOS, Paulo Roberto Barbosa; OLIVEIRA JUNIOR, Jorge Ferraz. Características do Ativismo Judicial nos Estados Unidos e no Brasil. Um breve histórico do ativismo judicial na Suprema Corte Norte-Americana e um Paralelo com o Recente Ativismo Judicial da Suprema Corte Brasileira. Revista de Informação Legislativa, Brasília, n. 204, p. 25-42, out/dez 2014. p. 37.

7 ZANETI JÚNIOR, Hermes. Processo Constitucional: O Modelo Constitucional do Processo Civil Brasileiro. Rio de Janeiro: Editora Lúmen Júris, 2007. p. 46.

8 CAMPOS, Carlos Alexandre de Azevedo. Dimensões do Ativismo Judicial do STF. Rio de Janeiro: Forense, 2014. p. 210. 
(art. 102, III, $a$, b e c). Ampliação dos legitimados à propositura de ADI. No regime anterior, apenas o Procurador-Geral da República, à época subordinado ao Presidente da República, detinha o monopólio da propositura. No atual regime, são legitimados (art. 103) o Presidente da República (I), a Mesa do Senado Federal (II), a Mesa da Câmara dos Deputados (III), a Mesa das Assembleias Legislativas (IV), o Governador de Estado (V), o Procurador-Geral da República (VI), o Conselho Federal da OAB (VII), os partidos políticos com representação no Congresso Nacional (inciso VIII) e as confederações sindicais ou entidades de classe de âmbito nacional (IX).

(iii) A EC3/93 criou a ação declaratória de constitucionalidade (ADC), atribuindo ao Presidente da República, às mesas do Senado e da Câmara dos Deputados e ao Procurador-Geral da República a legitimidade para a iniciativa.

(iv) No plano infraconstitucional, as Leis 9.868/1999 e 9.882/1999, que trazem normas processuais sobre a ADI, ADC e a ADPF, fortaleceram e expandiram os poderes do Supremo Tribunal Federal em relação ao controle concentrado de constitucionalidade, com a possibilidade de modulação temporal de efeitos, declaração de nulidade parcial sem redução do texto e participação de amici curiae. Com a ADPF, fica o Supremo Tribunal Federal autorizado a julgar se um determinado ato normativo federal, estadual ou municipal, mesmo que anterior à Constituição, afronta preceito fundamental.

(v) A EC 45/04 continuou o processo de empoderamento do Supremo Tribunal Federal, materializando a Reforma do Poder Judiciário. Ampliou o rol de legitimados à propositura da ADC (art. 103, caput), igualando-o ao rol de legitimados para a ADI. Além disso, deu status constitucional ao efeito vinculante da ADI (art. 102, § 2. ${ }^{\circ}$ ). Criou a figura da súmula vinculante (art. 103-A), bem como instituiu a repercussão geral como mais um requisito de admissibilidade de recurso extraordinário (art. 102, § 3.०). Essas alterações aportaram profundo incremento nos poderes do Supremo Tribunal Federal, aprofundando a sua participação na vida política do país, bem como a sua aproximação à ideia de uma Corte Constitucional.

Verifica-se, no entanto, que nos primeiros anos pós-1988 o Supremo Tribunal Federal não utilizou tais poderes de uma forma que se possa chamar de ativista, apesar de já se verificar o fenômeno do aumento da litigiosidade e da judicialização da política.

O Supremo Tribunal, reconfigurado pela CF/88, em seus primeiros anos, manteve a passividade que marcara o período pré-1988. O Tribunal, além de ter restringido alguns de seus poderes, também limitou o acesso à sua jurisdição. O grande exemplo é o mandado de injunção, a partir da adoção da teoria da proibição do judiciário como legislador positivo?.

\footnotetext{
9 BRASIL. Supremo Tribunal Federal. Questão de Ordem no Mandado de Injunção n. ${ }^{\circ}$ 107/DF. Tribunal Pleno. Relator Ministro Moreira Alves. J. 23.11.1989. DJ 21.09.1990. BRASIL. Supremo Tribunal Federal. Questão de Ordem no Mandado de Injunção n. ${ }^{\circ}$ 107/DF. Tribunal Pleno. Relator Ministro Moreira Alves. J. 23.11.1989. DJ 21.09.1990.
} 
Além disso, impôs limitações aos legitimados ativos para propositura de ADI's, em uma clara restrição aos termos do art. 103 da CF/88. Por exemplo, criou o conceito de pertinência temática, segundo o qual, para a propositura de ADI's os Governadores, Assembleias Legislativas, Confederações Sindicais e Entidades de Classe de âmbito nacional apenas poderiam propor ADI caso as leis e/ou atos normativos inquinados de inconstitucionalidade tivessem repercussão direta sobre os seus interesses ${ }^{10}$.

Houve, ainda, restrições criadas pela jurisprudência do Supremo Tribunal Federal à legitimidade para propositada de ADI’s em relação ao art. 103, IX, tendo entendido que associações de profissionais, associação de associações e federações sindicais não se ajustam aos conceitos de confederação sindical e entidades de classe ${ }^{11}$.

Também quando se tratou de medidas provisórias, o Supremo adotou uma postura passiva, entendendo que o controle de constitucionalidade sobre os pressupostos de relevância e urgência apenas seriam controláveis em caso de excesso de poder de legislar12.

Nos anos 2000, teve início a fase que se poderia chamar ativista na história do Supremo Tribunal Federal, com criação de direitos, fundamentos muitas vezes pouco de pobre fundamentação. No entanto, apresentaremos abaixo alguns constrangimentos que, apesar de o senso comum muitas vezes compreender na direção contrária, serviram como constrangimentos argumentativos, ou seja, a fundamentação foi constrangida, funcionando como um freio ao que se poderia chamar de excessiva discricionariedade.

\section{OS CONSTRANGIMENTOS A POSTERORI À DISCRICIONARIEDA- DE: VINCULAÇÃO AOS PRECEDENTES E INTERPRETAÇÃO EVO- LUTIVA (INCREMENTALISMO)}

No presente tópico, serão apresentados alguns constrangimentos importantes para conter o ativismo judicial ditos a posteriori. Deve-se esclarecer, de logo, que a preocupação deste trabalho não reside na criação de direitos pelo poder judiciário, atividade que, de resto, não contradiz a atual fase metodológica de nosso Direito, marcado pela superação ao Positivismo Legalista e pelo reconhecimento de um maior espectro

\footnotetext{
10 BRASIL. Supremo Tribunal Federal. Ação Direta de Inconstitucionalidade n. ${ }^{0}$ 1.096/RS. Tribunal Pleno. Relator Ministro Celso de Mello. J. 16.03.1995. DJ 22.09.1995.

11 BRASIL. Supremo Tribunal Federal. Ação Direta de Inconstitucionalidade n. ${ }^{\circ}$ 34/DF. Tribunal Pleno. Relator Ministro Octavio Gallotti. J. 05.04.1989. DJ 28.04.1989.

BRASIL. Supremo Tribunal Federal. Ação Direta de Inconstitucionalidade n. ${ }^{\circ}$.037/SC. Tribunal Pleno. Relator Ministro Moreira Alves. J. 03.06.1998. DJ 07.08.1998.

BRASIL. Supremo Tribunal Federal. Ação Direta de Inconstitucionalidade n. ${ }^{\circ}$ 17/DF. Tribunal Pleno. Relator Ministro Sydney Sanches. J. 11.03.1991. DJ 24.05.1991.

12 BRASIL. Supremo Tribunal Federal. Ação Direta de Inconstitucionalidade n. $162-M C$. Tribunal Pleno. Relator Ministro Moreira Alves. J. 14.12.1989. DJ 19.09.1997.
} 
interpretativo aos juízes e tribunais, com a natural inovação na ordem jurídica a partir da interpretação de textos.

A preocupação deste trabalho reside muito mais na fundamentação e como ela pode ser constrangida, sob pena de usurpação da atividade do legislador e de deslegitimação do próprio poder judiciário. A partir de uma fundamentação consistente, racional e clara é que o poder judiciário se desincumbe de seu verdadeiro papel e mantém sua legitimidade no desenho institucional traçado pela Constituição Federal de 1988.

Neste tópico, o trabalho abordará constrangimentos importantes e que devem ser valorizados pelas decisões judiciais, notadamente aquelas exaradas pelo Supremo Tribunal Federal. Antes de analisar os constrangimentos em si, todavia, o tópico começará por demonstrar como é possível falar em constrangimentos à fundamentação e como é possível falar, em consequência, em uma interpretação jurídica objetiva.

Para se falar em constrangimentos à interpretação e à fundamentação jurídicas, deve-se, primeiro, delinear a possibilidade da objetividade na interpretação jurídica, no sentido de Owen Fiss ${ }^{13}$. As normas não são normas, salvo se decorrem de um ato de autoridade, e aquela autoridade apenas pode ser conferida por uma comunidade. De acordo com esse entendimento, as regras que governam a atividade interpretativa devem ser vistas como definidoras ou demarcadoras de uma comunidade interpretativa que consiste naqueles que reconhecem as regras como vinculantes.

Isso significa que o caráter objetivo da interpretação está vinculado, limitado ou relativizado. Dessa forma, a fundamentação de uma decisão judicial é vinculada pela existência de uma comunidade que reconhece e adere às regras disciplinadoras usadas pelo intérprete e que é definida pelo reconhecimento daquelas regras. Uma objetividade vinculada é a única forma de objetividade à qual a lei - ou qualquer atividade interpretativa - pode aspirar e a única sobre a qual devemos nos preocupar. Nas palavras de Owen Fiss, "insistir em mais, procurar a decepcionante onipresença no céu, é criar uma falsa questão"14.

A objetividade diz, portanto, com a força cogente das normas e se o ato de julgar é constrangido ou limitado por elas; a correção, por sua vez, diz com o conteúdo das normas e se o processo de julgamento e o significado produzido por esse processo estão de acordo com aquele conteúdo. Dessa perspectiva, a legitimidade diz mais com a objetividade do que com a correção.

Os críticos da excessiva discricionariedade no exercício da jurisdição constitucional estão respondendo à preocupação de que sem uma busca pela objetividade das decisões, nós estaremos completamente à mercê do entendimento de cada juiz. Sem

\footnotetext{
13 FISS, Owen. Objectivity and Interpretation. Stanford Law Review, Stanford, v. 34, p. 739-763, abr. 1982. p. 740-745. 14 FISS, Owen. Objectivity and Interpretation. Stanford Law Review, Stanford, v. 34, p. 739-763, abr. 1982. p. 740-745.
} 
dúvida, é uma preocupação com fundamento, que remete à própria responsabilidade do juiz em relação às suas decisões 15 .

Se estamos tentando analisar o exercício da jurisdição constitucional e se não temos uma fórmula que garante chegar a resultados corretos, quais são os critérios para avaliarmos os julgamentos? Ou seja, até onde pode ir o juiz constitucional no seu mister? Qual é a diferença entre uma fundamentação absolutamente indefensável (se é que isso existe) e outra razoável, mesmo que indiscutivelmente errada? Em suma, o que faz do Direito mais um exercício de julgamento razoável, embora não puramente lógico, do que de aplicação de força arbitrária?

É precisamente a possibilidade de constrangimentos que pode levar à objetividade de uma fundamentação, no sentido mencionado acima, ou seja, de que a interpretação e a fundamentação podem ser constrangidas. Esses constrangimentos podem ser interpretativos, ou seja, impostos por métodos e teorias de interpretação, mas, também, por imposições processuais (p. ex., atenção a precedentes) e pragmáticas (interpretação evolutiva).

No presente tópico deste trabalho, o que se procura demonstrar é que os constrangimentos interpretativos, apesar de necessários, não são suficientes para uma adequada contenção da discricionariedade na interpretação do texto constitucional, fazendo-se necessários, igualmente, constrangimentos processuais e pragmáticos. É o que se demonstrará nos subitens seguintes.

\subsection{Constrangimentos interpretativos}

Não se pode esquecer, como bem destaca Krell, a importância do papel dessempenhado pelos métodos tradicionais da Hermenêutica Jurídica no sentido de estabelecer constrangimentos interpretativos, apesar de, nos últimos tempos, parecerem andar em baixa, ao menos no que concerne à interpretação da Constituição de 1988. Assim, os métodos gramatical, sistemático histórico e teleológico não devem ser desdenhados como constrangimentos interpretativos ${ }^{16}$, embora não sejam muitas vezes suficientes para justificar uma decisão.

Ao lado dos métodos clássicos acima mencionados, alguns importantes constitucionalistas construíram teorias de interpretação elaboradas e abrangentes para limitar a discricionariedade judicial. Ocorre que tais teorias partem do pressuposto equivocado de que a aplicação de uma ou algumas teorias específicas produzirão respostas corretas e indiscutíveis para uma qualquer questão constitucional. Por esse métodos,

\footnotetext{
15 POSNER, Richard A. The Problems of Jurisprudence. Cambridge: Harvard University Press. 1990. p. 272

16 KRELL, Andreas J. Entre Desdém Teórico e Aprovação na Prática: Os Métodos Clássicos de Interpretação Jurídica. Revista Direito GV, São Paulo, n. 10, p. 295-320, jan./jun. 2014.
} 
juristas (e alguns juízes) esperam eliminar a incerteza inerente à linguagem constitucional e, assim, reduzir a discricionariedade dos juízes.

Wilkinson III17 chama a essas teorias de cósmicas (cosmic constitutional theories) e, não sem uma forte dose de ironia, diz que elas pretendem desvendar os mistérios da constituição, tanto quanto Freud pretendeu fazer com o comportamento humano e Einstein tentou empreender em relação ao universo.

Certamente, as teorias (maximalismo, minimalismo, originalismo, constitucionalismo vivo, entre outras) são engenhosas, aportaram novos e importantes elementos à discussão sobre a interpretação constitucional e são, cada uma delas, defendidas por importantes juristas. No entanto, não lograram trazer a visão abrangente que os seus idealizadores e seguidores pretenderam e pretendem.

Ao menos dois fatores contribuem para que essas teorias tenham falhado na sua pretensão de conferir maior objetividade às decisões judiciais: a) a constituição não é, em última análise, uma abstração, mas fruto de uma experiência e de circunstâncias políticas e sociais; b) ela foi feita para incorporar tensões, o que torna a sua interpretação uma atividade mais complexa do que simples teorias a priori, por mais bem elaboradas que sejam, são capazes de resolver.

A fundamentação jurídica não é um exercício objetivo desconectado das diversas perspectivas e valores dos juízes. Os juízes não operam no vácuo e suas visões de mundo inevitavelmente moldam seus julgamentos - ao menos ou mais visivelmente - em casos difíceis. Mas, é evidente que os juízes estão sujeitos a constrangimentos específicos, diferentes daqueles a que se submetem os legisladores. Se os constrangimentos interpretativos não são suficientes, é necessário investigar outros constrangimentos processuais ou pragmáticos. São esses constrangimentos que se analisarão em seguida.

\subsection{O constrangimento representado pelo respeito aos precedentes}

Existem, de forma elementar, duas espécies de precedentes: os precedentes persuasivos (persuasive precedents) e os precedentes vinculantes (binding precedents). Na realidade brasileira, já estamos há muito tempo acostumados a lidar (embora mal) com a primeira espécie. Já em relação à segunda, no que diz respeito à atual ordem constitucional, foi adotada de forma expressa e regulamentada pela Constituição de 1988 (decisões do Supremo Tribunal Federal em sede de controle concentrado), pela Emenda Constitucional 45/2005 (súmulas vinculantes) e, por fim, pelo art. 927 do Código de Processo Civil de 2015 (acórdãos prolatados em incidentes de assunção de competência, em incidentes de resolução de demandas repetitivas, julgamento de recursos especiais e extraordinários repetitivos, enunciados de súmulas do Supremo Tribunal

17 WILKINSON III, J. Harvie. Cosmic Constitutional Theory. New York: Oxford University Press, 2012. p. 3. 
Federal em matéria constitucional e do Superior Tribunal de Justiça em matéria infraconstitucional, bem como a orientação do plenário ou do órgão especial dos tribunais aos quais o juiz está vinculado).

Como observa Teixeira18, a adoção de precedentes vinculantes, no sistema norte-americano, garante um grau relevante de previsibilidade e de aceitabilidade às decisões judiciais naquele ordenamento (no qual, observe-se, a jurisdição constitucional não é monopólio da Suprema Corte, assim como no Brasil), o que leva diversos outros países a reformar os seus ordenamentos para adotar sistemas semelhantes.

A aplicação eficaz dos precedentes, no entanto, requer uma adaptação em nossa prática judiciária, em que os relatórios são cada vez mais sucintos. Além dessas dificuldade, podem-se adicionar a forma de deliberação colegiada em nossos tribunais, que adotam o modelo per seriatim e não o modelo per curiam, que é adotado, esse último, pela Suprema Corte dos Estados Unidos.

No modelo per curiam, a corte exara apenas um voto vencedor, que constitui a opinion do colegiado. Essa sistemática facilita que se encontrem os motivos determinantes da decisão (holding ou ratio decidendi). No sistema per seriatim, a decisão final é um mosaico de votos individuais que, muitas vezes, chegam à mesma conclusão, mas sob fundamentos absolutamente diversos. Esse modelo torna extremamente difícil a identificação dos motivos determinantes e propicia a sensação de que o nosso Supremo Tribunal Federal, apesar para citar o exemplo mais representativo, é um conjunto de onze ilhas.

No sistema norte-americano, diferentemente, há uma experiência secular no trato da matéria, o que não acontece no nosso sistema, de tradição romano-germânica e em que o respeito a precedentes judiciais, apesar de vir se mostrando necessária ao longo do tempo, chega a soar até como antinatural. No nosso sistema, o que hoje chamamos de precedentes são muito mais decisões sobre teses do que sobre casos concretos.

Certo é, no entanto, que o Supremo Tribunal Federal não está legalmente adstrito a seus próprios precedentes, nem aqui se defende o contrário. Mas, sim, o artigo parte da ideia de que o Supremo Tribunal deve respeito a seus próprios precedentes, no sentido de que com eles as decisões posteriores devem dialogar, seja para confirmá -los, seja para afastá-los por distinção (distinguishing) ou superação (overrruling).

O juiz da Suprema Corte americana Lewis Powel19 disse que a "inevitabilidade da mudança toca o direito como toca qualquer aspecto da vida. Mas, estabilidade e moderação são particularmente importantes para o direito". E que "contenção ao julgar

\footnotetext{
18 TEIXEIRA, Ricardo Augusto de Araújo. Colhendo frutos da árvore venenosa: formação e uso dos precedentes no Brasil e nos EUA. Revista Brasileira de Direito Processual - RBDPro, Belo Horizonte, n. 72, ano 18, p. 189-213, out./dez. 2010. p. 192.

19 POWELL Jr., Lewis F. Stare decisis and judicial restraint. Washington and Lee Law Review, Washington, n. 2, v. 47, p. 289-299, mar. 1990. p. 293.
} 
e respeito às decisões anteriores são a chave para a preservação de um Judiciário independente e para o respeito público pelo papel do Judiciário como guardião dos direitos".

Também Benjamin Nathan Cardozo20 ressalta a importância da aderência aos precedentes, dizendo que "os juízes não são autorizados a fazer e desfazer regras ao seu bel-prazer de acordo com visões mutantes de conveniência e prudência". Ele reconhece, sim, que o respeito aos precedentes, evidentemente, não é garantia de um julgamento razoável ou "correto", mas que os precedentes judiciais ajudam na direção da objetividade, uniformidade, consistência e certeza das decisões judiciais, quando não fujam da razoabilidade e da conveniência.

Cardozo defende que "a lógica, a história, o costume, a utilidade e os padrões aceitos de conduta correta são as forças que sozinhas ou em combinação dão forma ao progresso do direito". Nesse conjunto de elementos, ele considera que os precedentes são um importante fator para dar coerência ao desenvolvimento do Direito, embora reconheça que a "uniformidade deixa de ser um valor quando se torna uniformidade de opressão". Aí é quando "o interesse social servido pela simetria ou certeza deve ser balanceado em relação ao interesse social servido pela equidade e justiça ou outros elementos do bem estar social"21.

A lição de Oliver Wendell Holmes segue a mesma senda22, ao destacar a importância da vinculação aos precedentes, ressalva, por outro lado, que os precedentes devem ser constantemente submetidos ao escrutínio e à revisão.

Na jurisprudência constitucional, a força do precedente se funda sobre uma razão adicional, que é a constituição como norma duradoura, destinada a estabilizar a vida política e social, subtraindo-a à inconstância das vicissitudes quotidianas: uma característica que seria evidentemente contraditada por uma jurisprudência constitucional que "andasse vagando", procedesse através de contradições em condição de contínua "emergência". Uma jurisprudência desse gênero teria inevitavelmente um valor "desconstrutivo", antes destrutivo, da constituição; seria em si mesma não um serviço da constituição, mas um atentado à sua natureza profunda23.

Sem dúvida, os precedentes funcionam como uma força a favor da objetividade (impessoalidade) e, consequentemente, redução da discricionariedade (voluntarismo) nos julgamentos. O precedente atua primariamente no sentido da manutenção da jurisprudência, reduzindo a discricionariedade do intérprete. Para que seja possível uma

\footnotetext{
20 CARDOZO, Benjamin Nathan. The Nature of the Judicial Process. Disponível em http://xroads.virginia.edu/ hyper/CARDOZO/CarNatl.html. Acesso em 08 de abril de 2014.

21 CARDOZO, Benjamin Nathan. The Nature of the Judicial Process. Disponível em http://xroads.virginia.edu/ hyper/CARDOZO/CarNatl.html. Acesso em 08 de abril de 2014.

22 HOLMES, Oliver Wendell. The common law. Disponível em http://www.gutenberg.org/files/2449/2449-h/2449-h.htm. Acesso em 13 de maio de 2014. p. 12.

23 ZAGREBELSKY, Gustavo; MARCENÓ, Valeria. Giustizia costituzionale. Bologna: Il Mulino Strumenti, 2012. p. 113.
} 
mudança de curso, do intérprete se exige um ônus argumentativo mais denso, pois terá que demonstrar que o caso sob julgamento é diferente do caso albergado (distinguishing) pelo precedente ou que o precedente deve ser superado (overruling) por razões fáticas ou jurídicas.

\subsection{O incrementalismo ou a interpretação constitucional evolutiva}

Além dos métodos de interpretação, sejam os clássicos, seja os concebidos nas últimas décadas, bem como dos precedentes como fatores de contenção da discricionariedade judicial, há um outro elemento que pode contribuir de forma importante para a racionalidade e a contenção pretendidas às decisões judiciais.

Com efeito, os juízes frequentemente devem fazer escolhas entre aplicações plausíveis ou entendimentos diferentes. Essas escolhas serão influenciadas por uma miríade de fatores, incluindo elementos subjetivos do juiz, o poder de persuasão dos advogados, a clareza ou não do texto, a existência de precedentes, entre diversos outros fatores que influenciam o processo de decisão.

Esses fatores algumas vezes podem conduzir à contenção e outras, não. Mas, há um fator que deveria ser levado em conta pelos juízes e que talvez funcionasse mais como um freio do que como um estimulante a posturas excessivamente discricionárias: a preferência pelo incrementalismo/interpretação evolutiva, ao invés de se optar por mudanças radicais de entendimento.

O Direito existe porque há a necessidade de se regularem relações entre as pessoas. Ele prescreve padrões de comportamento, supostamente refletindo os valores da sociedade. O papel do juiz é entender o propósito do direito na sociedade e ajudá-lo a atingir esse propósito. Mas, por outro lado, o direito de uma sociedade é um organismo vivo e o juiz é um importante ator dessa mudança. Todavia, a necessidade de mudança requer também uma preocupação com a estabilidade, o que implica que a mudança deve ocorrer por evolução e não por revolução24.

Decerto, a construção do significado da norma constitucional não deve conduzir ao subjetivismo, ou à construção de significados que prestigiam as concepções pessoais do intérprete. Esse é o fundamento da chamada interpretação evolutiva, ou seja, a garantia de que não haverá rupturas, mas que, ao contrário, a jurisprudência deverá caminhar cautelosamente em uma dada direção.

Na prática do Direito Constitucional norte-americano, a interpretação evolutiva desempenha papel de grande relevo, tanto no campo do devido processo legal como no da criação de novos direitos não previstos expressamente (e.g., o direito à privacidade) e no da igualdade perante a lei, notadamente a de cunho racial.

24 BARAK, Aharon. A judge on Judging. The Role of a Supreme Court in a Democracy. Harvard Law Review, Cambridge, n. 116, p. 97-113, nov. 2002. p. 100. 
A esse propósito, é ilustrativo assinalar que a versão original da Carta de 1787 permitia, na Seção 2 do art. 1. ${ }^{\circ}$ o regime de escravidão. Em 1857, ao julgar o caso Dred Scott vs. Sandford, a Suprema Corte chegou a negar a condição de cidadão a um es-

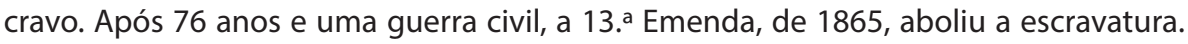
Investidos de cidadania, ainda assim os negros eram discriminados, com a chancela dos poderes estatais 25 , dentre outras formas, mediante a segregação nas escolas, nos transportes públicos e nas zonas residenciais de diversas cidades, inclusive do norte.

Em 1896, ao decidir o caso Plessy vs. Ferguson, a Suprema Corte endossou a doutrina do equal but separate - iguais, mas separados -, forma dissimulada de discriminação praticada em diversos Estados. Somente em 1954, ao julgar Brown vs. Board of Education, a Corte considerou inconstitucional a segregação de estudantes negros nas escolas públicas, em decisão que se tornou um marco na política de integração racial. Constata-se, assim, que, na vigência de uma mesma Constituição, o tratamento dado aos negros evoluiu da discriminação total para a discriminação atenuada, e, depois, para a não-discriminação26.

Dessa forma, a interpretação evolutiva (ou incrementalista) permite a adaptabilidade da constituição às novas realidades sociais, mas sem sobressaltos, sem movimentos abruptos e sim, ao contrário, por alterações minimalistas e prudentes, em que o exercício da discricionariedade judicial é medido e cauteloso.

Estabelecido neste tópico do trabalho que as teorias interpretativas são elementos necessários, mas não suficientes a uma fundamentação o mais racional possível e que, ao lado delas, deve um tribunal dialogar com seus próprios precedentes, bem como respeitar a linha evolutiva de sua jurisprudência e do próprio sistema como um todo, analisar-se-á, no tópico seguinte, um acórdão do Supremo Tribunal que, em nossa visão, representa um exemplo de fundamentação racional e constrangida (no sentido de limitada) pelos elementos aqui analisados, apesar de parte do senso comum entendê-la como irrazoável e ativista.

\section{ANÁLISE DE CASOS JULGADOS PELO SUPREMO TRIBUNAL FE- DERAL: INCREMENTALISMO (JURISPRUDÊNCIA EVOLUTIVA) E RESPEITO A PRECEDENTES}

No presente tópico, será analisado julgamento prolatado pelo Supremo Tribunal Federal muitas vezes apontado como ativista e irrazoável. A ideia é demonstrar como o Supremo Tribunal Federal, no caso analisado, adotou entendimento inovador,

\footnotetext{
25 BARROSO, Luís Roberto. O Direito Constitucional e a Efetividade de suas Normas. 1. ed. Rio de Janeiro: Renovar, 1990. p. 152.

26 BARROSO, Luís Roberto. O Direito Constitucional e a Efetividade de suas Normas. 1. ed. Rio de Janeiro: Renovar, 1990. p. 152.
} 
efetivador de direitos fundamentais e socialmente relevantes mas, nem por isso, ativista, no sentido de excessivamente discricionários e pouco constrangidos.

O caso que será analisados abaixo exemplifica julgamento em que o Supremo Tribunal Federal, sem se demitir de sua função de guardião da Constituição, logrou evitar o ativismo, dando passos ousados mas, ao mesmo tempo, calcados no respeito à evolução dos temas respectivos no Direito Brasileiro e por ela constrangidos.

\subsection{O caso das Uniões Homoafetivas (ADI 4.277 e da ADPF 13227)}

No caso das uniões homoafetivas, o Supremo Tribunal reinterpretou os significados dos conceitos de homem e mulher para reconhecer as uniões de pessoas do mesmo sexo, no julgamento da ADI n. 4.277 e da ADPF n. ${ }^{\circ} 132$, da relatoria do Min. Carlos Ayres Britto, com julgamento em 5/5/2011. No julgamento dessas ações, o Supremo Tribunal fez a interpretação conforme do artigo 1.723 do Código Civil, de sorte a entender pela mutação constitucional do artigo 226, § 3.० , da Constituição Federal, para reconhecer a pessoas do mesmo sexo o regramento infraconstitucional da união estável (no caso em julgamento, união homoafetiva).

As ações foram reunidas em julgamento único. A ADI n. 4277 foi proposta pelo Procurador Geral da República e a ADPF n. ${ }^{\circ} 132$, pelo Governador do Estado do Rio de Janeiro.

O voto vencedor demonstra que o termo e a ideia de "homoafetividade", utilizado para identificar o vínculo de afeto e solidariedade entre os pares ou parceiros do mesmo sexo, não são antigos na sociedade brasileira. Na sua argumentação, fica claro que a linha é demonstrar que a distinção de sexos, na forma anátomo-fisiológica como vinha sendo interpretada, perdeu sentido na modernidade.

No julgamento em tela, o Supremo entendeu que os conceitos de homem e mulher, ao menos para fins de união estável, se alterara e que os conceitos já sedimentados em bases biológicas não poderiam subsistir. Assim, entendeu por conferir interpretação conforme ao art. 1.723 do Código Civil para impedir qualquer interpretação que impeça a união estável entre pessoas do mesmo sexo.

A solução final dada ao caso suscitou críticas de ativismo porque homem e muIher, segundo os críticos, são conceitos definidos e largamente incontroversos, explicitamente tratados pela Constituição, em seu art. 226, § 3. ("Para efeito da proteção do Estado, é reconhecida a união estável entre o homem e a mulher como entidade familiar, devendo a lei facilitar sua conversão em casamento." g.n.) e pelo art. 1.723 do Código Civil.

27 BRASIL. Supremo Tribunal Federal. Ação Direta de Inconstitucionalidade n. 4277 e Arguição de Descumprimento de Preceito Fundamental n. ${ }^{\circ}$ 132. Tribunal Pleno. Relator Ministro Celso de Melo. J. 05/05/2011. DJ 14.10.2011. 
No entanto, apesar da interpretação inovadora em relação aos conceitos de homem e mulher adotados pela legislação, aqui é importante se ter em conta que o ordenamento brasileiro já desde há alguns anos vinha progressivamente reconhecendo direitos aos casais homoafetivos, o que indica que o Supremo Tribunal seguiu uma linha evolutiva e foi por ela constrangido.

Com efeito, para citar alguns poucos exemplos, o Superior Tribunal de Justiça, no Recurso Especial 148.897/MG28, reconhecera a existência de direito a partilha de bens entre membros de casais homoafetivos 29.

No julgamento do Recurso Especial 395.904 (STJ, 2005)30, por sua vez, foi reconhecida a condição de dependente do parceiro homoafetivo perante o INSS para fins previdenciários. O RESP 395.904 foi julgado em sede de Ação Civil Pública ajuizada peranta a 3.a Vara Federal Previdenciária de Porto Alegre (ACP 2000.71.00.009347-0). Por efeito de decisão proferida na ACP, o INSS editou a INSTRUÇÃO NORMATIVA INSS/ DC No 25, DE 07 DE JUNHO DE 2000 - DOU DE 08/06/2000, reconhecendo a condição de dependente do parceiro homoafetivo, dando mais um passo no sentido do reconhecimento de direitos inerentes a uniões estáveis homoafetivas.

No julgamento do RESP 238.71531, a seu turno, o Tribunal reconheceu o direito de o parceiro homoafetivo ser beneficiário em plano de saúde privado.

No plano legislativo infraconstitucional, a Lei 11.340/2006 (Lei Maria da Penha), em seu art. 5.o, incisos e parágrafo único, estabeleceu um importante marco em relação aos direitos de gênero ao sancionar a violência doméstica contra a mulher. O mencionado parágrafo único dispõe que "as relações sexuais enunciadas neste artigo independem de orientação sexual".

No âmbito do próprio Supremo Tribunal Federal, houve uma importante sinalização no julgamento da ADI 3.300 (STF, 2006). Aquela ADI fora ajuizada para que o Supremo Tribunal prolatasse a inconstitucionalidade do art. 1.o da Lei n. 9.278/96 e, assim, reconhecesse as uniões homoafetivas. Ocorre que aquele dispositivo legal foi supervenientemente revogado pelo art. 1.723 do Código Civil, razão por que a ADI foi extinta.

No entanto, o relator, em sua decisão extintiva, fez importante sinalização, em um prenúncio do futuro julgamento da ADI 4.277 e da ADPF 13, ora analisadas e em cujo julgamento o Supremo Tribunal reconheceu as uniões homoafetivas, conferindo interpretação conforme justo ao art. 1.723 do Código Civil, que prejudicara o prosseguimento da ADI 3.300 .

\footnotetext{
28 BRASIL. Superior Tribunal de Justiça. Recurso Especial n. ${ }^{\circ}$ 148.897. Quarta Turma. Relator Ministro Ruy Rosado de Aguiar. J. 10.02.1998. DJ 06.04.1998.

29 Esse precedente foi seguido em diversos outros julgamentos, como nos RESP`s 323.370, 502.995 e 773.136.

30 BRASIL. Superior Tribunal de Justiça. Recurso Especial 395904. Quinta Turma. Relator Ministro Hélio Quaglia Barbosa. J. 13.12.2005. DJ 06.02.2006.

31 BRASIL. Superior Tribuanl de Justiça. Recurso Especial n. ${ }^{\circ}$ 238715. Terceira Turma. Relator Ministro Humberto Gomes de Barros. J. 07.03.2006. DJ 02.10.2006.
} 
Com efeito, a relativamente extensa decisão do Relator Min. Celso de Mello extinguiu a ADI 3.30032 em razão da questão processual apontada, mas não sem antes tecer argumentação no sentido do reconhecimento dos direitos dos casais homoafetivos, como exemplifica o trecho:

9. A aceitação das uniões homossexuais é um fenômeno mundial - em alguns países de forma mais implícita - como alargamento da compreensão do conceito de família dentro das regras já existentes; em outros de maneira explícita, com a modificação do ordenamento jurídico feita de modo a abarcar legalmente a união afetiva entre pessoas do mesmo sexo. 10. O Poder Judiciário não pode se fechar às transformações sociais, que, pela sua própria dinâmica, muitas vezes se antecipam às modificações legislativas.

Como se vê, apesar de o julgamento do Supremo Tribunal Federal na ADI 4.277 e da ADPF 13 ser aparentemente impactante e inovador, aqui também o ordenamento brasileiro já vinha progressivamente seguindo uma linha de reconhecimento de direitos a pessoas que mantêm uniões homoafetivas, como direitos sucessórios, patrimoniais e previdenciários. O Supremo Tribunal apenas seguiu a linha evolutiva do ordenamento brasileiro quanto ao tema e foi por ela constrangido.

Por essa razão, em nosso entendimento, o Supremo Tribunal Federal, também no julgamento da ADI 4.277 e da ADPF 13 não se comportou de forma ativista, uma vez que não construiu uma argumentação ad hoc, valendo-se de uma discricionariedade inapropriada a julgamentos, com laivos de atividade tipicamente legislativa.

Ao contrário, o Supremo, no caso em análise, seguiu uma linha evolutiva já estabelecida durante anos no ordenamento brasileiro, para, no julgamento da ADI 4.277 e da ADPF 13, dialogando com essa mesma linha evolutiva, culminar com a efetivação de normas constitucionais de amplo reconhecimento pelo Direito nacional.

\section{CONCLUSÕES}

Como se demonstrou ao longo do texto, este artigo tem por objetivo principal responder à pergunta: existem constrangimentos eficazes para o ativismo e a discricionariedade judicial, além de meros constrangimentos representados pelos limites semânticos dos textos normativos e de teorias interpretativas?

A ampliação interpretativa e o crescimento do papel do Poder Judiciário no Brasil e em diversos outros países, como é o caso dos Estados Unidos da América e da República Francesa, do Estado de Israel, da Colômbia, do Chile, do Canadá, do Japão, entre

32 BRASIL. Supremo Tribunal Federal. Ação Direta de Inconstitucionalidade n. 3300 MC/DF. Decisão monocrática. Relator Ministro Celso de Mello. J. 03.02.2006. DJ 09.02.2006. 
diversos outros, têm levado a uma postura, ao menos no campo teórico e acadêmico, de preocupação com os limites ao exercício da jurisdição constitucional.

$\mathrm{O}$ que este trabalho buscou foi refletir em que medida e por que meios seria possível equilibrar o saudável exercício do controle de constitucionalidade - necessário, em nosso entender, ao bom funcionamento das democracias - com a deferência às deliberações dos poderes majoritários - que, apesar da deturpação prática de seu papel ainda são, entre os poderes do Estado, aqueles que de forma mais abrangente podem representar os interesses coexistentes em uma sociedade hipercomplexa.

Os constrangimentos expostos (precedentes e interpretação evolutiva da constituição), na visão do artigo, atuam no sentido de limitar a discricionariedade no exercício da jurisdição constitucional. Nesse contexto é que o julgamento do Supremo Tribunal Federal analisado no artigo (caso das uniões homoafetivas) visa a demonstrar que essa Corte fundamentou, nesse julgamento, de forma constrangida por precedentes e pela interpretação evolutiva da Constituição e que, sob esse ponto de vista, esse julgamento é exemplar.

O caminho apontado, portanto, vai no sentido de que se não é de se negar a importância dos constrangimentos linguísticos e hermenêuticos aos excessos da jurisdição constitucional, sejam eles clássicos ou recentes, deve-se, outrossim, reconhecer que esses constrangimentos não são suficientes, pois que textos e palavras podem ser manipulados (e o são) facilmente pelo operador do direito. Mais eficazes se mostram os constrangimentos processuais e pragmáticos, como o respeito aos precedentes e a interpretação evolutiva.

\section{REFERÊNCIAS}

BARAK, Aharon. A judge on Judging. The Role of a Supreme Court in a Democracy. Harvard Law Review, Cambridge, n. 116, p. 97-113, nov. 2002.

BARROSO, Luís Roberto. O Direito Constitucional e a Efetividade de suas Normas. 1. ed. Rio de Janeiro: Renovar, 1990.

BRASIL. Supremo Tribunal Federal. Questão de Ordem no Mandado de Injunção n. ${ }^{0}$ 107/DF. Tribunal Pleno. Relator Ministro Moreira Alves. J. 23.11.1989. DJ 21.09.1990.

BRASIL. Supremo Tribunal Federal. Mandado de Injunção n. ${ }^{\circ}$ 232. Tribunal Pleno. Relator Ministro Moreira Alves. J. 02.08.1991. DJ 27.03.1992.

BRASIL. Supremo Tribunal Federal. Mandado de Injunção n. ${ }^{\circ}$ 670. Tribunal Pleno. Relator Ministro Maurício Corrêa. Relator para acórdão Min. Gilmar Mendes. J. 25.10.2007. DJ 31.10.2008.

BRASIL. Supremo Tribunal Federal. Ação Direta de Inconstitucionalidade n. ${ }^{0}$ 1.096/RS. Tribunal Pleno. Relator Ministro Celso de Mello. J. 16.03.1995. DJ 22.09.1995. 
BRASIL. Supremo Tribunal Federal. Ação Direta de Inconstitucionalidade n. ${ }^{\circ}$ 34/DF. Tribunal Pleno. Relator Ministro Octavio Gallotti. J. 05.04.1989. DJ 28.04.1989.

BRASIL. Supremo Tribunal Federal. Ação Direta de Inconstitucionalidade n. ${ }^{\circ}$ 1.037/SC. Tribunal Pleno. Relator Ministro Moreira Alves. J. 03.06.1998. DJ 07.08.1998.

BRASIL. Supremo Tribunal Federal. Ação Direta de Inconstitucionalidade n. ${ }^{0}$ 17/DF. Tribunal Pleno. Relator Ministro Sydney Sanches. J. 11.03.1991. DJ 24.05.1991.

BRASIL. Supremo Tribunal Federal. Ação Direta de Inconstitucionalidade n. ${ }^{\circ}$ 162-MC. Tribunal Pleno. Relator Ministro Moreira Alves. J. 14.12.1989. DJ 19.09.1997.

BRASIL. Supremo Tribunal Federal. Mandado de Segurança n.' 23.642-DF. Tribunal Pleno. Relator Ministro Néri da Silveira. J. 29.11.2000. DJ 11.12.2000.

BRASIL. Supremo Tribunal Federal. Ação Direta de Inconstitucionalidade n. 3300 MC/DF. Decisão monocrática. Relator Ministro Celso de Mello. J. 03.02.2006. DJ 09.02.2006.

BRASIL. Supremo Tribunal Federal. Ação Direta de Inconstitucionalidade n. 4277 e Arguição de Descumprimento de Preceito Fundamental n. 132. Tribunal Pleno. Relator Ministro Celso de Melo. J. 05/05/2011. DJ 14.10.2011.

BRASIL. Superior Tribunal de Justiça. Recurso Especial n. ${ }^{0}$ 148.897. Quarta Turma. Relator Ministro Ruy Rosado de Aguiar. J. 10.02.1998. DJ 06.04.1998.

BRASIL. Superior Tribunal de Justiça. Recurso Especial 395904. Quinta Turma. Relator Ministro Hélio Quaglia Barbosa. J. 13.12.2005. DJ 06.02.2006.

BRASIL. Superior Tribuanl de Justiça. Recurso Especial n. ${ }^{\circ} 238715$. Terceira Turma. Relator Ministro Humberto Gomes de Barros. J. 07.03.2006. DJ 02.10.2006.

CAMPOS, Carlos Alexandre de Azevedo. Dimensões do Ativismo Judicial do STF. Rio de Janeiro: Forense, 2014.

CARDOZO, Benjamin Nathan. The Nature of the Judicial Process. Disponível em <http://xroads. virginia.edu/ hyper/CARDOZO/CarNatl.html>. Acesso em 08 de abril de 2014.

CONTINENTINO, Marcelo Casseb. Ativismo Judicial. Proposta para uma discussão conceitual. Revista de Informação Legislativa, Brasília, a. 49, n. 193, p. 141-149, jan/mar 2012.

DANTAS, Ivo. Constituição Federal. Teoria e Prática. Rio de Janeiro: Renovar. 1994.

FISS, Owen. Objectivity and Interpretation. Stanford Law Review, Stanford, v. 34, p. 739-763, abr. 1982.

HOLMES, Oliver Wendell. The common law. Disponível em <http://www.gutenberg.org/files/2449/2449-h/2449-h.htm>. Acesso em 13 de maio de 2014.

KMIEC, Keenan. The origin and current meaning of "judicial activism. Disponível em <http:// www.constitution.org//rev/kmiec/judicial_activism.htm>. Acesso em 08.07.2014. 
KRELL, Andreas J. Entre Desdém Teórico e Aprovação na Prática: Os Métodos Clássicos de Interpretação Jurídica. Revista Direito GV, São Paulo, n. 10, p. 295-320, jan-jun/2014.

NOBRE JÚNIOR, Edílson Pereira. Ativismo judicial: possibilidade e limites. Revista de Direito Administrativo e Constitucional, Belo Horizonte, n. 43, ano 11, p. 92-117, jan./mar. 2011.

PACHECO, José da Silva. Mandado de segurança e outras ações constitucionais típicas. 5. ed. São Paulo: Editora Revista dos Tribunais, 2008.

POWELL Jr., Lewis F. Stare decisis and judicial restraint. Washington and Lee Law Review, Washington, n. 2, v. 47, p. 289-290, mar. 1990.

RAMOS, Paulo Roberto Barbosa; OLIVEIRA JUNIOR, Jorge Ferraz. Características do Ativismo Judicial nos Estados Unidos e no Brasil. Um breve histórico do ativismo judicial na Suprema Corte Norte-Americana e um Paralelo com o Recente Ativismo Judicial da Suprema Corte Brasileira. Revista de Informação Legislativa, Brasília, n. 204, p. 25-42, out/dez 2014.

ROMBOLI, Roberto. A função interpretativa do juiz comum e a influência sobre ela exercida pela jurisprudência constitucional. In: ROMBOLI, Roberto; ARAÚJO, Marcelo Labanca Corrêa de (Coord.). Justiça Constitucional e Tutela Jurisdicional dos Direitos Fundamentais. Belo Horizonte: Arraes Editores, 2015, p. 40-60.

STRECK, Lenio Luiz. Verdade e Consenso. São Paulo: Saraiva. 2012.

TEIXEIRA, Ricardo Augusto de Araújo. Colhendo frutos da árvore venenosa: formação e uso dos precedentes no Brasil e nos EUA. Revista Brasileira de Direito Processual - RBDPro, Belo Horizonte, n. 72, ano 18, p. 189-213, out./dez. 2010.

WILKINSON III, J. Harvie. Cosmic Constitutional Theory. New York: Oxford University Press, 2012. ZAGREBELSKY, Gustavo; MARCENÓ, Valeria. Giustizia costituzionale. Bologna: II Mulino Strumenti, 2012.

ZANETI JÚNIOR, Hermes. Processo Constitucional: O Modelo Constitucional do Processo Civil Brasileiro. Rio de Janeiro: Editora Lúmen Júris, 2007. 